\title{
Screening Cotoneaster for Resistance to Fire Blight by Artificial Inoculation
}

\author{
Joseph J. Rothleutner ${ }^{1}$ \\ The Morton Arboretum, 4100 Illinois Route 53, Lisle, IL 60532
}

\author{
Ryan N. Contreras ${ }^{2,4}$ \\ Department of Horticulture, Oregon State University, 4017 Agricultural and \\ Life Sciences Building, Corvallis, OR 97331
}

Virginia O. Stockwell ${ }^{3}$

Department of Botany and Plant Pathology, Oregon State University, Corvallis, OR 97331

\section{James S. Owen ${ }^{2}$}

Department of Horticulture, Virginia Polytechnic Institute and State University, Hampton Roads Agricultural Research and Extension Center, Virginia Beach, VA 23455

Additional index words. Erwinia amylovora, Rosaceae, Maloideae, foliar assay

\begin{abstract}
Cotoneaster Medik. is a genus of ornamental landscape plants commonly affected by fire blight. Fire blight is a disease caused by the bacterial pathogen, Erwinia amylovora (Burrill) Winslow et al., that attacks a wide range of taxa in the apple subfamily (Maloideae; Rosaceae). To assess susceptibility of species and identify potential sources of resistance, we inoculated 52 taxa of Cotoneaster with $E$. amylovora. Disease severity was scored by percent shoot necrosis (lesion length/total shoot length). Disease screenings were conducted over 2 years and varying levels of susceptibility were observed. Some taxa were highly susceptible to fire blight and the disease resulted in whole plant mortality ( $C$. rhytidophyllus Rehder \& E.H. Wilson, $C$. rugosus E. Pritzel ex Diels, and $C$. wardii W.W. Smith). Other taxa repeatedly exhibited moderate to high levels of disease resistance [C. arbusculus G. Klotz, $C$. chungtinensis (T.T. Yu) J. Fryer \& B. Hylmö, $C$. delsianus E. Pritzel var. delsianus, $C$. sikangensis Flinck \& B. Hylmö, $C$. simonsii Baker, and $C$. splendens Flinck \& Hylmö]. Ongoing studies are being conducted to determine if taxa with high levels of resistance under artificial inoculation will exhibit high levels of resistance in the field under natural disease pressure. Identifying sources of disease resistance will be useful for breeding programs to increase tolerance of these landscape plants with desirable horticultural characteristics to fire blight.
\end{abstract}

Cotoneaster is a diverse genus of over 400 species ranging in form from groundcovers to trees. The center of diversity for the genus is in Tibet and the Himalayas, but species are native across continental Asia, North Africa, and Europe (Bartish et al., 2001; Dickoré and Kasperek, 2010; Fryer and Hylmö, 2009). Cotoneaster is commonly used in managed landscapes as durable, low-maintenance ornamental shrubs where they are valued for multiseason interest for flowers, foliage, and fruiting characteristics. Although Cotoneaster generally is robust and easy to cultivate, many taxa are susceptible to the bacterial disease fire blight caused by Erwinia amylovora. Disease

Received for publication 29 July 2014. Accepted for publication 8 Oct. 2014.

This study is from a thesis submitted by J.J.R. as partial fulfillment of the degree of M.S.

We thank Mara Friddle for technical support.

${ }^{1}$ Tree Improvement Specialist.

${ }^{2}$ Assistant Professor.

${ }^{3}$ Assistant Professor/Senior Researcher.

${ }^{4}$ To whom reprint requests should be addressed; e-mail ryan.contreras@oregonstate.edu. through rain, wind, and visiting insects. The pathogen enters the plant through wounds or natural openings; flowers are particularly vulnerable. Infected shoots first appear water-soaked and then develop a scorched appearance, often with a characteristic shepherd's crook. When bark of infected plants is removed, discolored vascular tissue may be seen. Fire blight will quickly kill entire plants if the disease progresses to the crown. In addition to threatening the health of the plant, the necrotic tissue is unsightly and devalues nursery and landscape plants. Fire blight is managed through labor-intensive sanitation or prophylactic applications of copper or antibiotics, where permitted (van der Zwet and Beer, 1999). Host resistance, as a first line of defense in an integrated pest management plan, could greatly reduce the need for chemical inputs and allow for more extensive planting of resistant taxa.

Screening for fire blight resistance in ornamentals such as Malus Tourn ex L., Pyrus L., Pyracantha M. Roem., and Cydonia Mill. has demonstrated a wide range of susceptibility within these genera (Bell et al., 2004; Bouma, 1990; Lespinasse and Aldwinckle, 2000; van der Zwet and Beer, 1999). Screening for fire blight resistance in Cotoneaster has been relatively limited with only a portion of the genus screened. Previous screenings of Cotoneaster germplasm has resulted in the release of cultivars with fire blight resistance including $C$. salicifolius Franchet 'October Glory' and 'Willeki', $C$. henryanus (C.K. Schneider) Rehder \& E.H. Wilson 'Corina' (Fryer and Hylmö, 2009), and C. dammeri C.K. Schneider 'Eicholz' (Bellenot-Kapusta et al., 2002), 'Holsteins Resi', and 'Thiensen' (Losing, 1992). Persiel and Zeller $(1978,1981,1990)$ showed there was varying resistance within sexual populations of diploid species, which has allowed for selection of resistant taxa.

Many species of Cotoneaster are reported to be apomictic clones (Dickoré and Kasperek, 2010; Fryer and Hylmö, 2009) and currently there are no known selections for fire blight resistance from these species. In addition, most reports on fire blight resistance in Cotoneaster have been observational studies under landscape conditions without testing by artificial inoculation (Davis and Peterson, 1976; Hodgkin and Fletcher, 1965; Jorgensen and Jensen, 1978; New Jersey Agricultural Experiment Station, 1932; Zeller, 1979). Disease occurrence often varies between years and environments; therefore, results from observational surveys under low disease pressure may be inconclusive. Examination of disease development in Cotoneaster under controlled artificial inoculation may clarify the list of resistant taxa. Our objective was to evaluate susceptibility of a collection of Cotoneaster after inoculation with a virulent strain of fire blight under glasshouse conditions.

\section{Materials and Methods} inoculum for infection within and among nearby plants (van der Zwet and Beer, 1999). The bacteria are dispersed primarily
Plant material and culture conditions. The germplasm was obtained mostly as 
open-pollinated seed from Index Seminum from a range of botanic gardens and institutions across the world. In addition, a few plants were obtained from commercial Oregon nurseries $(C$. hortizontalis Decaisne 'Variegatus', C. ×suecicus G. Klotz 'Coral Beauty', and C. thymifolius Baker). All taxa were grown in above-ground containers and served as donor plants from which cuttings were collected. Rooted cuttings were transferred to 1.65-L containers (Gauge Dura-Pot, Lake Oswego, OR) with a custom substrate composed of one pumice:two peat:seven douglas-fir [Pseudotsuga menziesii (Mirb.) Franco] bark with standard nursery amendments (Rexius, Eugene, OR) and liquid-fed weekly (Jack's Professional 20N-8.74P-16.6K with micronutrients; J.R. Peters Laboratory, Allentown, PA) and watered by hand, as needed. Aphids and other pests were managed with M-pede ${ }^{\circledR}$ (Gowan Company, Yuma, AZ). Plants were maintained in a glasshouse with day/night set temperatures of $25 / 16{ }^{\circ} \mathrm{C}$ to encourage growth and then inoculated when average shoot length was $\approx 30 \mathrm{~cm}$. All plants were vigorously growing at the time of inoculation. This study took place over 2 consecutive years.

A total of 52 taxa were screened in this study. In Year 1 (2011), 31 taxa were screened (Table 1). In Year 2 (2012), 35 taxa were screened (Table 2). Fourteen of the taxa evaluated in 2011 were screened again to assess consistency between both years of the study.

In both years, plants were arranged in a randomized complete block design with three blocks and three plants per taxa per block. Also included in each block was a negative control plant on which two leaves were bisected with scissors that were dipped in sterile deionized water to confirm that observed lesions were not the result of a wound response.

Inoculation and disease severity rating. The pathogen strain for this study was $E$. amylovora strain Ea153. Strain Ea153 was isolated from diseased Malus $\times$ domestica Borkh. 'Gala' apple trees in eastern Oregon and its pathogenicity has been demonstrated in numerous field trials (Stockwell et al., 2011). The pathogen was cultured in $200 \mathrm{~mL}$ Kings medium B broth in a 1-L flask for $48 \mathrm{~h}$ at $27^{\circ} \mathrm{C}$ on a rotary shaker (200 RPM). After $48 \mathrm{~h}$, cells were pelleted by centrifugation $(3220 \mathrm{~g}, 10 \mathrm{~min})$ and mixed with powdered skim milk [38\% (w/w)]. The bacterial suspension was lyophilized, ground to a fine powder, and frozen at $-80{ }^{\circ} \mathrm{C}$. Titer was calculated by dilution plating. Bacteria were re-suspended in sterile deionized water to a concentration of $10^{9}$ colony-forming units (cfu)/mL in 2011 and concentration was reduced to $10^{7} \mathrm{cfu} / \mathrm{mL}$ in 2012 as a result of a calculation error.

In Year 1, plants were inoculated on 3 Mar. 2011 and final lesion length measurements were taken on 24 May 2011. In Year 2, plants were inoculated on 27 Feb. 2012 and final measurements were taken on 23 Apr. 2012. Glasshouse temperatures were recorded during both years (Fig. 1). Plants were inoculated by bisecting the two youngest leaves on one shoot of each plant with scissors

Table 1. Percent shoot necrosis of Cotoneaster taxa inoculated with Erwinia amylovora strain Ea153 (109 colony-forming units $/ \mathrm{mL}$ ) in 2011 with a foliar bisection assay.

\begin{tabular}{|c|c|c|}
\hline Species & Accession & Percent shoot necrosis \\
\hline C.rhytidophyllus & $09-0020$ & $106.71^{y}$ \\
\hline C. wardii & $09-0026$ & $102.61^{\mathrm{y}}$ \\
\hline C. rugosus & 09-0021 & $102.24^{\mathrm{y}}$ \\
\hline C. braydii E.C. Nelson \& J. Fryer & 09-0076 & 87.19 \\
\hline C. salificolius var. floccosus & 09-0022 & 85.66 \\
\hline C. glabratus Rehder\& E.H. Wilson & 09-0016 & 79.46 \\
\hline C. applanatus E. Pritzel & 09-0067 & 79.30 \\
\hline C. nitens & 09-0052 & 68.81 \\
\hline C. cinerascens (Rehder) Flinck \& B. Hylmö & 09-0083 & 65.02 \\
\hline C. cashmeriensis G. Klotz & 09-0080 & 62.56 \\
\hline C. buxifolius & 09-0077 & 60.49 \\
\hline C. frigidus & 09-0045 & 59.34 \\
\hline C. amoenus E.H. Wilson & 09-0066 & 49.82 \\
\hline C. henryanus & 09-0017 & 47.57 \\
\hline C. turbinatus & $10-0096$ & 43.70 \\
\hline C.divarcatus Rehder \& E.H. Wilson & $10-0089$ & 32.66 \\
\hline C. bacillaris Wallich ex Lindley & 09-0073 & 27.39 \\
\hline C. zabelii C.K. Schneider & 09-0027 & 15.78 \\
\hline C. hebephyllus Diels & $10-0091$ & 15.39 \\
\hline C. cochleatus & 09-0085 & 14.09 \\
\hline C. congestus Baker & $10-0088$ & 9.72 \\
\hline C. sternianus & $09-0025$ & 2.56 \\
\hline C. atrovirens & 09-0072 & 2.02 \\
\hline C. simsonii & 09-0023 & 0.43 \\
\hline C. chungtinensis & 09-0082 & 0.35 \\
\hline C. franchetii & 09-0015 & 0.00 \\
\hline C. arbusculus & 09-0068 & 0.00 \\
\hline C. atropurpureus & 09-0071 & 0.00 \\
\hline C. dielsianus var. dielsianus & 09-0013 & 0.00 \\
\hline C. sikangensis & $10-0095$ & 0.00 \\
\hline C. splendens & 09-0024 & 0.00 \\
\hline
\end{tabular}

${ }^{2}$ Mean percent shoot necrosis from fire blight, Tukey's honestly significant difference value $0.1060(P<0.05)$ ${ }^{y}$ Shoot necrosis greater than $100 \%$ signifies that the symptoms of fire blight extended beyond the inoculated shoot toward the crown and resulted in plant death.

dipped in the bacterial suspension. The necrotic lesion length was measured weekly for 8 weeks post-inoculation. The percent shoot necrosis, our measure of disease severity, was calculated as the final length of the lesion divided by the entire shoot length and expressed as an average percentage of the three plants within each block. The pathogen was re-isolated on Kings medium B from lesions 8 weeks after inoculation to confirm the presence of the bacterium as the causal agent for disease. Shavings were collected from two symptomatic taxa and one negative control in each block for a total of six plants with lesions and three negative controls. Shavings from each lesion margin were placed in $10 \mathrm{~mm}$ phosphate buffer and spread onto solidified Kings medium $\mathrm{B}$ amended with $50 \mu \mathrm{g} \cdot \mathrm{mL}^{-1}$ cycloheximide (Sigma-Aldrich, St. Louis, MO) to discourage growth of fungi and yeasts. Plates were incubated at room temperature for 48 to $72 \mathrm{~h}$, at which time the characteristic domed, white, mucoid colonies were visible. Lateral-flow immunoassay strips specific to E. amylovora were used to confirm the identity of isolated colonies as the pathogen (Braun-Kiewnick et al., 2011; BIOREBA, Reinach, Switzerland).

Data analysis. Disease severity data were analyzed within year by analysis of variance (ANOVA) (SAS Version 9.2; SAS Institute Inc., Cary, NC). The full model in ANOVA was used to test for species by year interaction and investigate disease ratings of checks between years. Area under disease progress curves (AUDPC) were calculated for species of interest and used to compare disease progression within and between years ( $\mathrm{R}$ Development Core Team, 2008; Shaner and Finney, 1977) using ANOVA (JMP ${ }^{\circledR}$ Pro Version 10.0.2; SAS Institute Inc.). Where appropriate, means were separated using Tukey's honestly significant difference $(P=$ $0.05)$. Plants demonstrating no disease incidence, as measured as the AUDPC in either 2011 or 2012 , were excluded from the analysis and considered potentially resistant.

In an attempt to clarify how our results correspond to the literature, disease sensitivity scores were also assigned to species in this study and to species covered in the literature. Disease sensitivity scores were assigned on a 3-point scale; 2 points were given for species noted as generally being susceptible to fire blight or to have greater than $10 \%$ shoot necrosis, 1 point was assigned when the taxon was described as having some resistance or between $5 \%$ and $10 \%$ shoot necrosis, and 0 points for species that were identified as resistant or highly resistant by the reporting authors and less than 5\% shoot necrosis in our study. An average score of sensitivity was also calculated by adding the sensitivity scores across the papers reporting for the species and dividing by the number of reporting papers (Table 3 ).

\section{Results}

Disease severity on taxa screened in Year 1. In 2011, the disease severity on inoculated 
plants ranged from $0 \%$ shoot necrosis to total plant death ( $100 \%$ shoot necrosis or greater). Control plants showed no symptoms of stem necrosis after leaf bisection with scissors dipped in sterile deionized water. The $100 \%$ or greater disease severity rating indicates that the disease symptoms extended beyond the inoculated shoot and into the crown of the
Table 2. Percent shoot necrosis of Cotoneaster taxa inoculated with Erwinia amylovora strain Ea153 (10 ${ }^{7}$ colony-forming units $/ \mathrm{mL}$ ) in 2012 with a foliar bisection assay.

\begin{tabular}{|c|c|c|}
\hline Species & Accession & Percent shoot necrosis ${ }^{z}$ \\
\hline C. rubens W.W. Smith & $10-0016$ & 62.17 \\
\hline C. shansiensis J. Fryer \& B. Hylmö & $10-0017$ & 54.11 \\
\hline C. horizontalis Variegatus & $10-0123$ & 53.55 \\
\hline C. thymifolius & $10-0122$ & 23.78 \\
\hline C. vilmorinianus $\mathrm{G}$. Klotz & $11-0010$ & 23.62 \\
\hline C. racemiflorus (Desfontaines) Booth ex Bosse & $10-0154$ & 21.00 \\
\hline C. vandelaarii J. Fryer \& B. Hylmö & $10-0139$ & 18.72 \\
\hline C. genitanus Hurus & $10-0132$ & 15.24 \\
\hline C. astrophorus J. Fryer \& B.Hylmö & $10-0127$ & 14.80 \\
\hline C. cochleatus & $09-0085$ & 12.47 \\
\hline C. lomaheunensis (Syn. C. poluninii G. Klotz) & $10-0136$ & 7.06 \\
\hline C. procumbens G. Klotz & $10-0137$ & 6.22 \\
\hline C. acutifolius & $10-0126$ & 4.67 \\
\hline C. henryanus $\mathrm{x}$ & $09-0017$ & 3.86 \\
\hline C. congestus ${ }^{\mathrm{x}}$ & $10-0088$ & 3.47 \\
\hline C. lidjiangensis & $10-0135$ & 1.75 \\
\hline C. $\times$ suecicus Coral Beauty & $10-0166$ & 1.68 \\
\hline C. dielsianus var. dielsianus ${ }^{\mathrm{y}}$ & $09-0013$ & 1.51 \\
\hline C. sternianus & $09-0025$ & 1.34 \\
\hline C. divarcatus $\mathrm{x}^{\mathrm{x}}$ & $10-0089$ & 0.77 \\
\hline C. simsonii ${ }^{\mathrm{y}}$ & $09-0023$ & 0.69 \\
\hline C. arbusculus ${ }^{\mathrm{y}}$ & $09-0068$ & 0.00 \\
\hline C. atrovirens & $09-0072$ & 0.00 \\
\hline C. boisianus & $09-0047$ & 0.00 \\
\hline C. bullatus & 09-0012 & 0.00 \\
\hline C. chungtinensis ${ }^{\mathrm{y}}$ & $09-0082$ & 0.00 \\
\hline C. daliensis & $10-0129$ & 0.00 \\
\hline C. fastigiatus & $10-0013$ & 0.00 \\
\hline C. frigidus $\mathrm{s}^{\mathrm{x}}$ & $09-0045$ & 0.00 \\
\hline C. hypocarpus & $10-0133$ & 0.00 \\
\hline C. milkedandaensis & $10-0174$ & 0.00 \\
\hline C. pannosus & $09-0046$ & 0.00 \\
\hline C. salicifolius var. floccosus ${ }^{\mathrm{x}}$ & $09-0022$ & 0.00 \\
\hline C. sikangensis ${ }^{\mathrm{y}}$ & $10-0095$ & 0.00 \\
\hline C. splendens ${ }^{\mathrm{y}}$ & $09-0024$ & 0.00 \\
\hline
\end{tabular}

plant and also confirms the virulence of strain Ea153 on Cotoneaster species. Plants of three of the species tested (C. rhytidophyllus, $C$. rugosus, and $C$. wardii) were highly susceptible and were killed by the pathogen.

Some species showed no symptoms and other species appeared to show levels of quantitative resistance, whereby only a portion of the shoot was necrotic (Table 1). Mean separation of species did not discern between species exhibiting $0 \%$ to $11 \%$ shoot necrosis, meaning that plants with $11 \%$ shoot necrosis were not statistically different from plants that expressed no symptoms. This range was too wide to be applicable for our cultivar selection program; therefore, a tolerance threshold of $5 \%$ shoot necrosis was used to identify highly resistant plants. Six of the 30 taxa screened in the first year showed no shoot necrosis; these were $C$. arbusculus, $C$. atropurpureus Flinck \& B. Hylmö, C. delsianus, $C$. franchetii Bois, $C$. sikangensis, and $C$. splendens. In addition, four other species, $C$. atrovirens J. Fryer \& B. Hylmö, C. chungtinensis, C. simsonii Baker, and C. sternianus (Turrill) Boom, had under 5\% shoot necrosis. The 10 species identified as resistant in 2011 were screened again in 2012 to confirm disease resistance with the exception of $C$. atropurpureus and $C$. franchetii, which had failed to yield enough asexual propagules for repeated testing.

Disease severity on taxa screened in Year 2. In 2012, disease symptoms did not appear to be as severe as in the previous year; disease severity at the end of the study ranged from $0 \%$ to $62 \%$ (Table 2 ).

Statistically, there was no difference among species with $0 \%$ to $6 \%$ shoot necrosis. All of the species that were identified as highly resistant in 2011 ( $5 \%$ or less disease severity; Table 1) that were repeated in 2012 also appeared highly resistant in the 2012

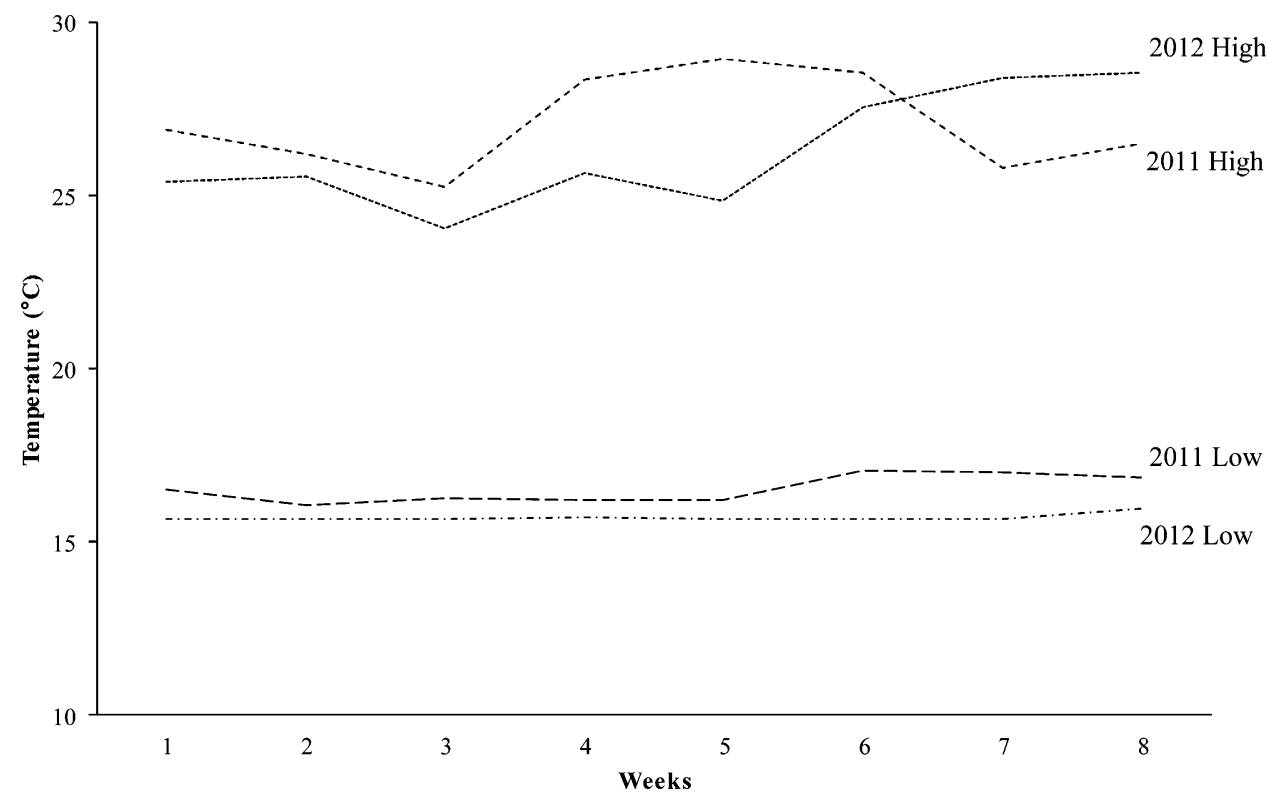

Fig. 1. High and low temperatures recorded for the duration of both 8-week disease screening trials during 2011 and 2012 in the glasshouse where plants were grown. 


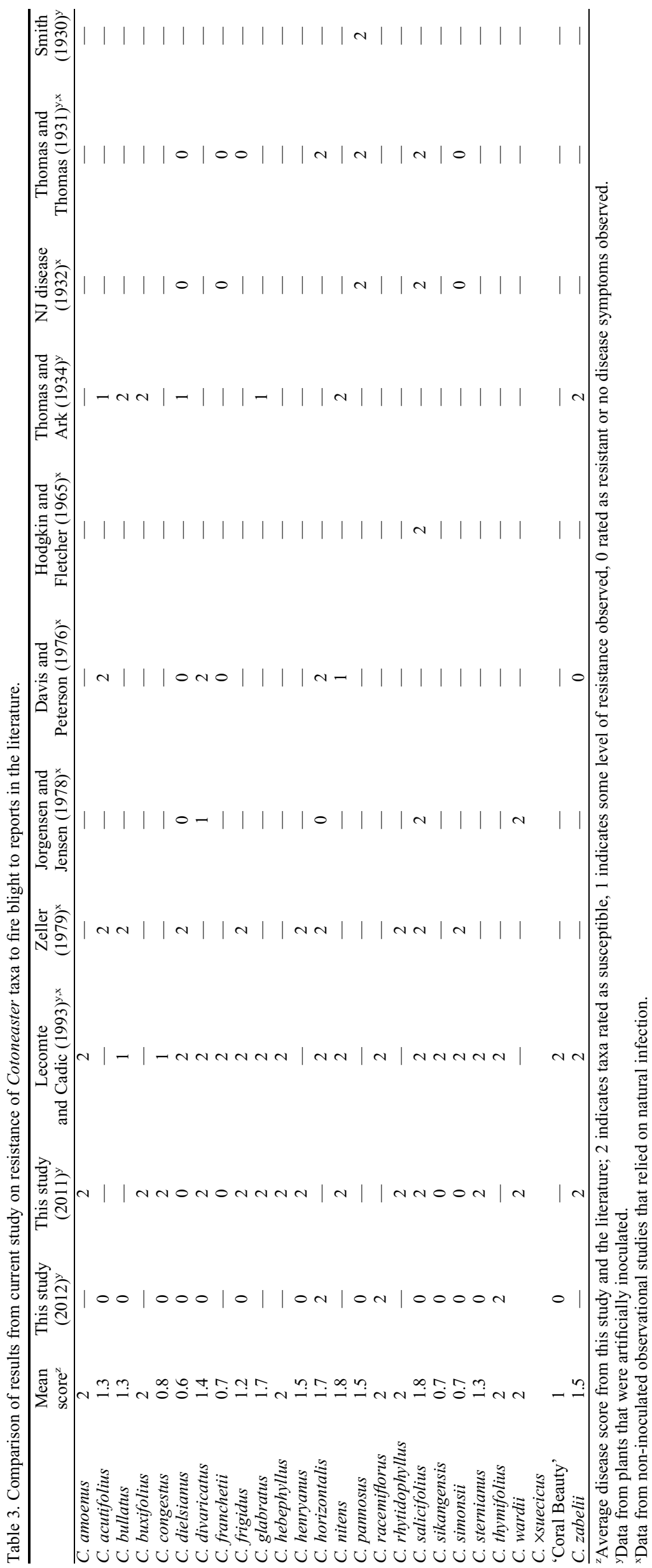

screening (Table 2). Additional taxa that were only tested in the second year and scored as highly resistant included $C$. acutifolius Turczaninov, C. boisianus G. Klotz, $C$. bullatus Bois, C. daliensis J. Fryer \& B. Hylmö, C. fastigiatus J. Fryer \& B. Hylmö, C. hypocarpus J. Fryer \& B. Hylmö, C. lidjiangensis G. Klotz, C. milkedandaensis J. Fryer \& B. Hylmö, C. pannosus Franchet, and $C$. Xsuecicus 'Coral Beauty'.

\section{Discussion}

In this study, we identified several taxa of Cotoneaster with resistance to fire blight using a tolerance threshold of 5\% to identify highly resistant taxa, because only low levels of damage are acceptable in the nursery industry and in landscapes where aesthetics are of high importance. To our knowledge, this study is the first to rate fire blight susceptibility after artificial inoculation with the pathogen in 27 taxa of Cotoneaster. Twelve of these species showed no symptoms of fire blight inoculation. Additionally, C. arbusculus, $C$. sikangensis, and $C$. splendens were screened in both 2011 and 2012 and expressed no symptoms in either year, suggesting a high level of resistance.

Disease severity was also examined in species that expressed symptoms by calculating AUDPC for species that were not susceptible (Table 4), unique to each year (Table 5), and for those screened in both years (Table 6). Year, species, and their interaction proved to be statistically significant $(P<0.001)$ when we compared the disease symptoms between the 2 years. Effects from environmental variables that are difficult to control, even in a glasshouse environment, likely were driving forces for differences in disease pressure between years. Smith and Pusey (2011) discuss the impact that temperature has on the growth rate of the bacteria, but the interaction is more complex than only the impact on the pathogen. In our study, the primary effect would have been on the rate of growth of the pathogen and plant growth rate; those plants that are growing faster presumably would have been more susceptible to infection. Although year had a significant interaction with disease response, we observed consistent trends between years for many species and $C$. frigidus Wallich ex Lindley, $C$. henryanus, and $C$. salicifolius were the only species for which there were statistical differences between years for AUDPC (Table 6).

In general, results obtained in this study were positively correlated with those previously reported. Cotoneaster nitens Rehder \& E.H. Wilson was susceptible in our study (Table 1) and reported as susceptible by others including Davis and Peterson (1976), Lecomte and Cadic (1993), and Thomas and Ark (1934) (Table 3). Some conflicts in susceptibility ratings of species of Cotoneaster within the literature and from our results were observed. For example, C. simsonii exhibited only low levels of disease severity 
Table 4. Potentially resistant Cotoneaster taxa that had no disease symptoms as measured as the area under the disease progress curve when inoculated with Erwinia amylovora Ea153 under controlled conditions in $2011\left(10^{9}\right.$ colony-forming units/ $\mathrm{mL})$ or $2012\left(10^{7}\right.$ colony-forming units $\left./ \mathrm{mL}\right)$.

\begin{tabular}{|c|c|c|}
\hline $\mathrm{Yr}$ & Taxon & Accession \\
\hline \multirow[t]{5}{*}{$\overline{2011}$} & C. arbusculus $^{z}$ & $09-0068$ \\
\hline & C. atropurpureus & 09-0071 \\
\hline & C. delsianus var. delsianus & 09-0013 \\
\hline & C. sikangensis ${ }^{\mathrm{z}}$ & $10-0095$ \\
\hline & C. splendens ${ }^{\mathrm{z}}$ & 09-0024 \\
\hline \multirow[t]{13}{*}{2012} & C. arbusculus ${ }^{z}$ & 09-0068 \\
\hline & C. atrovirens & 09-0072 \\
\hline & C. boisianus & $09-0047$ \\
\hline & C. bullatus & 09-0012 \\
\hline & C. chungtinensis & 09-0082 \\
\hline & C. daliensis & $10-0129$ \\
\hline & C. fastigiatus & $10-0013$ \\
\hline & C. frigidus & $09-0045$ \\
\hline & C. milkdedandaensis & $10-0174$ \\
\hline & C. pannosus & 09-0046 \\
\hline & C. salicifolius var. floccosus & 09-0022 \\
\hline & C. sikangensis ${ }^{z}$ & $10-0095$ \\
\hline & C. splendens ${ }^{\mathrm{z}}$ & 09-0024 \\
\hline
\end{tabular}

${ }^{\mathrm{z}}$ Species was screened in both 2011 and 2012.

in our study $(0.43 \%$ shoot necrosis in 2011 and $0.69 \%$ in 2012; Tables 1 and 2), whereas this species was rated as susceptible by Lecomte and Cadic (1993) and by Zeller (1979) but also was identified as resistant by the New Jersey Agricultural Experiment Station (1932) and Thomas and Thomas (1931) (Table 3). Many variables may be responsible for these conflicts; for example, there may be variation in susceptibility among selections of the species that were tested in Europe in the 1970s and 1990s and those tested in the United States in the 1930s. Additionally, some of the reported results were from ratings after artificial inoculation (e.g., Bellenot-Kapusta et al., 2002; Persiel and Zeller, 1981) and others from natural infection observations (e.g., Jorgensen and Jensen, 1978; New Jersey Agricultural Experiment Station, 1932). In studies where artificial inoculation was used to determine susceptibility to fire blight, inoculum concentration ranged from $10^{6} \mathrm{cfu} / \mathrm{mL}$ to $10^{9} \mathrm{cfu} / \mathrm{mL}$ or in some cases was not specified. Bellenot-Kapusta et al. (2002) inoculated using titers at concentrations ranging from $10^{6} \mathrm{cfu} / \mathrm{mL}$ to $10^{8} \mathrm{cfu} / \mathrm{mL}$. No correlation of inoculation titer to disease susceptibility was reported, but plant vigor was suspected to influence the disease severity (Bellenot-Kapusta et al., 2002). We cannot rule out that titer was not responsible for differences between years but their findings provide support that other factors are involved. Plant vigor and growth may be correlated to temperature and environmental factors, which may also influence the pathogenicity of fire blight. In our study there were many different species used between years, which may have different inherent growth rates in addition to having levels of resistance. Mean shoot length at the time of inoculation in our study was $30 \mathrm{~cm}$; however, some species are large and very fast growing, whereas others are extremely small and only grow a few centimeters per year. Inherent growth rate

Table 5. Disease incidence as measured as the area under the disease progress curve (AUDPC) for Cotoneaster taxa evaluated for fire blight susceptibility in either 2011 or 2012 but not in both years.

\begin{tabular}{|c|c|c|c|}
\hline $\mathrm{Yr}$ & Species & Accession & AUDPC \\
\hline \multirow[t]{15}{*}{$\overline{2011^{z}}$} & C. rhytidophyllus & $09-0020$ & 1.0671 \\
\hline & C. wardii & 09-0026 & 1.0261 \\
\hline & C. rugosus & 09-0021 & 1.0224 \\
\hline & C. braydi & 09-0076 & 0.8719 \\
\hline & C. glabratus & $09-0016$ & 0.7946 \\
\hline & C. applanatus & $09-0067$ & 0.793 \\
\hline & C. nitens & $09-0052$ & 0.6881 \\
\hline & C. cinerascens & 09-0083 & 0.6502 \\
\hline & C. cashmiriensis & 09-0080 & 0.6256 \\
\hline & C. buxifolius & 09-0077 & 0.6049 \\
\hline & C. amoenus & 09-0066 & 0.4982 \\
\hline & C. turbinatus & $10-0096$ & 0.437 \\
\hline & C. bacillaris & $09-0073$ & 0.2739 \\
\hline & C. zabelii & $09-0027$ & 0.1578 \\
\hline & C. hebephyllus & $10-0091$ & 0.1539 \\
\hline \multirow[t]{14}{*}{$2012^{y}$} & C. rubens & $10-0016$ & 0.6217 \\
\hline & C. shansiensis & $10-0017$ & 0.5411 \\
\hline & C. horizontalis 'Variegatus' & $10-0123$ & 0.5355 \\
\hline & C. thymifolius & $10-0122$ & 0.2378 \\
\hline & C. vilmorinianus & $11-0010$ & 0.2362 \\
\hline & C. racemiflorus & $10-0154$ & 0.21 \\
\hline & C. vandelaarii & $10-0139$ & 0.1872 \\
\hline & C. genitianus & $10-0132$ & 0.1524 \\
\hline & C. astrophoros & $10-0127$ & 0.148 \\
\hline & C. lomahuensis & $10-0136$ & 0.0706 \\
\hline & C. procumbens & $10-0137$ & 0.0622 \\
\hline & C. acutifolius & $10-0126$ & 0.0467 \\
\hline & C. lidjiangensis & $10-0135$ & 0.0175 \\
\hline & C. ×suecicus 'Coral Beauty' & $10-0166$ & 0.0168 \\
\hline
\end{tabular}

${ }^{\mathrm{z}_{\mathrm{HSD}}}$ value of 0.4341 for 2011 at $P<0.0001$.

${ }^{\mathrm{y}} \mathrm{HSD}$ value of 0.301 for 2012 at $P<0.0001$.

$\mathrm{HSD}=$ honestly significant difference.

Table 6. Simple effects (species $\times$ year) for disease incidence as measured as the area under the disease progress curve for individual Cotoneaster taxa evaluated for fire blight susceptibility in both 2011 and in 2012.

\begin{tabular}{|c|c|c|c|c|}
\hline Species & Accession & $2011^{z}$ & 2012 & $\begin{array}{c}P \\
\text { value }\end{array}$ \\
\hline C. atrovirens & $09-0072$ & 0.0202 & 0.0000 & 0.3322 \\
\hline C. chungtiensis & 09-0082 & 0.0035 & 0.0000 & 0.3322 \\
\hline C. cochleatus & $09-0085$ & 0.1409 & 0.1247 & 0.8833 \\
\hline C. congestus & $10-0088$ & 0.0972 & 0.0347 & 0.3497 \\
\hline C. dielsianus & $09-0013$ & 0.0000 & 0.0151 & 0.1501 \\
\hline C. divaricatus & $10-0089$ & 0.3266 & 0.0077 & 0.0563 \\
\hline C. frigidus & $09-0045$ & 0.5934 & 0.0000 & $<0.0001$ \\
\hline C. henryanus & 09-0017 & 0.4757 & 0.0386 & 0.0051 \\
\hline C. salicifolius & 09-0022 & 0.8566 & 0.0000 & $<0.0001$ \\
\hline C. simsonsii & $09-0023$ & 0.0043 & 0.0069 & 0.7475 \\
\hline C. sternianus & $09-0025$ & 0.0256 & 0.0134 & 0.6570 \\
\hline
\end{tabular}

${ }^{\mathrm{z}}$ Honestly significant difference value of 0.0527 at significant difference within column in $2011, P<$ 0.0001 . No significant differences were observed among species in 2012.

differences combined with the fact that temperatures were different between years, which can also affect the growth rate of the pathogen, and it is not surprising that we observed differences between years.

We did not investigate the mechanisms of resistance influencing lesion length in our study. We observed, however, that some species exhibited an apparent hypersensitive response in inoculated leaves, although we did not perform microscopic analysis. On inoculated leaves of $C$. chungtinensis and $C$. delsianus var. delsianus, the leaves were necrotic at the inoculation site and then rapidly shriveled and abscised before disease symptoms progressed into the stem. Nonetheless, leaf abscission was not observed with all resistant species. Many resistant species such as $C$. arbusculus and $C$. splendens maintained healthy green leaves after inoculation with little or no necrosis observed even at the bisection site.

Maas Geesteranus and Heyting (1978) proposed that under natural insect vectoring and disease pressure, small or pubescent-leaved species of Cotoneaster exhibit less disease, possibly because the leaf morphology is less hospitable for insect vectors of the pathogen. We did not observe this trend with artificially inoculated plants, because some large fleshy-leaved species (C. arbusculus and $C$. bullatus) were resistant to fire blight and some small hairy-leaved species ( $C$. buxifolius Wallich ex Lindley and C. thymifolius) were susceptible. From a breeding perspective, resistance by vector avoidance would only provide low levels of security in nursery 
production. In nurseries, the plants are regularly handled, sheared, and kept under overhead irrigation. Nursery production practices may provide wounds and promote environments that could contribute to an outbreak of fire blight independent of wounding and vectoring by insects. Therefore, breeding to increase resistance based on vector avoidance may reduce the incidence of disease in landscapes but would not be an effective mechanism to control disease in production nurseries.

We observed a range of susceptibility in Cotoneaster species to fire blight and identified several taxa that showed consistent resistance. Artificial inoculation in a glasshouse proved to offer an effective means to evaluate resistance to fire blight. Future work will continue to evaluate additional species for resistance as well as investigating heritability of resistance among species and interspecific hybrids. Evaluation of susceptibility through floral inoculation may also yield useful information, because pollinators are often a vectoring agent of the disease in the landscape and outbreaks of fire blight in fruit orchard systems are most severe when flowers are infected (van der Zwet and Beer, 1999).

\section{Literature Cited}

Bartish, I.V., B. Hylmö, and H. Nybom. 2001. RAPD analysis of interspecific relationships in presumably apomictic Cotoneaster species. Euphytica 120:273-280.

Bell, A.C., T.G. Ranney, T.A. Eaker, and T.B. Sutton. 2004. Resistance to fire blight among flowering pears and quince. J. Amer. Hort. Sci. 40:413-415.

Bellenot-Kapusta, V., R. Chartier, M.N. Brisset, and J.P. Paulin. 2002. Selection of a genotype of Cotoneaster with a high level of resistance to fireblight. Acta Hort. 590:385-392.
Bouma, A.S. 1990. Breeding Pyracantha for fire blight resistance. Acta Hort. 273:327-334.

Braun-Kiewnick, A., D. Altenbach, T. Oberhänsli, W. Bitterlin, and B. Duffy. 2011. A rapid lateral-flow immunoassay for phytosanitary detection of Erwinia amylovora and on-site fire blight diagnosis. J. Microbiol. 87:1-9.

Davis, S.H., Jr. and L.J. Peterson. 1976. Susceptibility of Cotoneaster to fire blight. J. Arboriculture 2:90-91.

Dickoré, W.B. and G. Kasperek. 2010. Species of Cotoneaster (Rosaceae, Maloideae) indigenous to, naturalizing or commonly cultivated in Central Europe. Willdenowia 40:13-45.

Fryer, J. and B. Hylmö. 2009. Cotoneasters; a comprehensive guide to shrubs for flowers, fruit and foliage. Timber Press, Portland, OR.

Hodgkin, B.M. and J.T. Fletcher. 1965. The fire blight campaign in southend-on-sea. NAAS Quarterly Review 67:106-110.

Jorgensen, H.A. and A. Jensen. 1978. Natural infection of host plants in the Danish "fireblight gardens." Acta Hort. 86:11-13.

Lecomte, P. and A. Cadic. 1993. Further results on shoot susceptibility of Cotoneaster to fire blight. Acta Hort. 338:407-412.

Lespinasse, Y. and H.S. Aldwinckle. 2000. Breeding for resistance to fire blight, p. 253-268. In: Vanneste, J.L. (ed.). Fire blight: The disease and its causal agent, Erwinia amylovora. CABI Publishing, New York, NY.

Losing, H. 1992. Cotoneaster dammeri: Fire blight (Erwinia amylovora) resistant cultivars in Germany. Proceedings of IPPS 42:123-124.

Maas Geesteranus, H.P. and J. Heyting. 1978. Greenhouse test on fire blight susceptibility of species and cultivars of ornamental Pomoideae. Acta Hort. 86:41-43.

New Jersey Agricultural Experiment Station. 1932. Fire blight in ornamentals. Nursery disease notes. New Jersey Agricultural Experiment Station. 5:1.

Persiel, F. and W. Zeller. 1978. Differences in susceptibility to fireblight, Erwinia amylovora
(Burr) Winslow et al., in non apomictical species, varieties and ecotypes of Cotoneaster. Acta Hort. 86:45-50.

Persiel, F. and W. Zeller. 1981. Some progress in breeding Cotoneaster for resistance to fireblight, Erwinia amylovora (Burr) Winslow et al. Acta Hort. 117:83-87.

Persiel, F. and W. Zeller. 1990. Breeding upright growing forms of Cotoneaster for resistance to fireblight, Erwinia amylovora (Burr) Winslow et al. Acta Hort. 273:297-301.

R Development Core Team. 2008. R: A language and environment for statistical computing. $\mathrm{R}$ Foundation for Statistical Computing, Vienna, Austria. 1 May 2012. <http://www.R-project.org>.

Shaner, G. and R.E. Finney. 1977. The effect of nitrogen fertilization on the expression on slow-mildewing resistance in Knox wheat. Phytopathology 67:1051-1056.

Smith, C. 1930. Pear blight on Cotoneaster. Phytopathology 20:922.

Smith, T.J. and P.L. Pusey. 2011. Cougarblight 2010, a significant update of the Cougarblight fire blight infection risk model. Acta Hort. (ISHS) 896:331-336.

Stockwell, V.O., K. Johnson, D. Sugar, and J. Loper. 2011. Mechanistically compatible mixtures of bacterial antagonists improves biological control of fire blight of pear. Phytopathology 101:113-123.

Thomas, H.E. and P.A. Ark. 1934. Fire blight of pears and related plants. University of California Berkeley Agricultural Experiment Station Bulletin 586.

Thomas, H.E. and H.E. Thomas. 1931. Plants affected by fire blight. Phytopathology 21: 425-435.

van der Zwet, T. and S.V. Beer. 1999. Fire blight-Its nature, prevention and control: A practical guide to integrated disease management. U.S. Department of Agriculture, Agriculture information bulletin 631

Zeller, W. 1979. Resistance breeding in ornamentals. EPPO Bulletin 9:35-44 